\title{
Graphitic carbon nitride/carbon brush composite as a novel anode for yeast-based microbial fuel cells
}

\author{
Enas Taha Sayed ${ }^{1,2^{*}}$, Mohammad Ali Abdelkareem ${ }^{1,2,3}$, Hussain Alawadhi ${ }^{1,4^{*}}$, Khaled Elsaid ${ }^{5}$, \\ Tabbi Wilberforce ${ }^{6}$, A.G. Olabi ${ }^{1,3,6^{*}}$ \\ ${ }^{1}$ Center for Advanced Materials Research, University of Sharjah, 27272, Sharjah, United Arab Emirates \\ ${ }^{2}$ Chemical Engineering Department, Faculty of Engineering, Minia University, Egypt \\ ${ }^{3}$ Department of Sustainable and Renewable Energy Engineering, University of Sharjah, 27272, Sharjah, United Arab \\ Emirates \\ ${ }^{4}$ Department of Applied Physics and Astronomy, University of Sharjah, PO Box 27272, Sharjah, United Arab \\ Emirates \\ ${ }^{5}$ Chemical Engineering Program, Texas A\&M University, College Station, TX, 77843-3122, USA. \\ ${ }^{6}$ School of Engineering and Applied Science, Aston University, Birmingham B4 7ET, UK \\ *Corresponding authors: A.G. Olabi (aolabi@sharjah.ac.ae), and Enas Taha Sayed (e.kasem@mu.edu.eg).
}




\begin{abstract}
A biocompatible graphitic carbon nitride $\left(\mathrm{g}-\mathrm{C}_{3} \mathrm{~N}_{4}\right)$ was prepared on the surface of carbon brush fiber $(\mathrm{CB})$ via a facile one-step preparation method. The prepared $\mathrm{g}-\mathrm{C}_{3} \mathrm{~N}_{4}$ formed a composite with the carbon brush's fibers $\left(\mathrm{g}-\mathrm{C}_{3} \mathrm{~N}_{4} @ \mathrm{CB}\right)$, as shown from the XRD analysis. The $\mathrm{g}-\mathrm{C}_{3} \mathrm{~N}_{4} @ \mathrm{CB}$ was used as an anode in a yeast-based microbial fuel cell (MFC), and demonstrated an outstanding performance compared to plain CB. An anode potential of $-0.27 \mathrm{~V}$ "vs. Ag/AgCl" and an opencircuit voltage of $0.77 \mathrm{~V}$ was obtained in the case of the composite electrode, compared to $-0.1 \mathrm{~V}$ vs. $\mathrm{Ag} / \mathrm{AgCl}$ and $0.62 \mathrm{~V}$, respectively, in the case of the $\mathrm{CB}$. The cell using the composite electrode demonstrated a maximum power of $772 \mathrm{mWm}^{-2}$, which is twelve times that obtained using the CB. The outstanding performance of the composite electrode can be credited to the biocompatibility of the composite anode and its roughness, which improved the yeast biofilm formation and decreased the ohmic resistance. This is the first report involving the application of g- $\mathrm{C}_{3} \mathrm{~N}_{4}$ in a yeast-based $\mathrm{MFC}$, and it demonstrated promising results which can be used for other types of MFCs.
\end{abstract}

\title{
Keywords:
}

Yeast based MFC; graphitic carbon nitride; composite electrode; impedance spectroscopy; biofilm. 


\section{Introduction}

Energy demand increases daily because of both increase in technology use and increasing population. This energy relies on conventional energy sources, i.e. fossil fuels $[1,2]$. Due to the side effects associated with the consumption of these energy sources, such as energy exhaustion, limited resources, and negative effects on the environment [3-5], the performance of existing energy conversion technologies must be improved [6-9] and/or replace this type of energy with renewable energies [10-12], such as solar energy [13-15], biomass energy [16-18], geothermal energy $[19,20]$, ocean energy [21, 22], and wind energy [23, 24]. Because of the problems associated with wastewater discharge, its treatment is important from both an environmental perspective and from a water shortage perspective [25]. While wastewater contains a considerable portion of energy (biomass), the current water treatment technologies are intensive energy consuming processes [26].

Fuel cells (FCs) are efficient devices, used for electricity generation from the chemical energy of fuels [27-29]. Microbial fuel cells (MFCs) are a type of fuel cell that use the metabolic reaction of a microorganism to simultaneously convert the chemical energy contained in biomass to electricity, while treating wastewater at ambient conditions [30-32]. Recently, they used for simultaneous water desalination and wastewater treatment $[33,34]$ and/or biohydrogen production $[35,36]$. At the anaerobic anode, in order to generate electrons and protons, microorganisms use organic materials in waste water. Via an external circuit (flow of electrons resulting in electricity generation), the electrons are passed to the cathode side, while the protons are migrated through the membrane. The electrons and protons react with oxygen from the atmosphere at the cathode, forming water. The movement of electrons-directly or indirectly- from interior of the 
microorganisms to the anode surface plays a crucial role in deciding the efficiency of MFCs [37, 38].

Due to the simple structure of prokaryotics, i.e., no cell compartments and small size, several strains have been already reported as effective microorganisms in MFCs, without the need for additional external mediators, such as different Shewanella strains [39], Geobacter [40], Escherichia coli [41], and others. Compared to the prokaryotes, eukaryotes such as yeast strains are capable of metabolising complex organic materials that usually exist in wastewater streams $[32,42]$. Among different eukaryotes, Saccharomyces cerevisiae is a cheap and easily cultivated option, which can be stored for in a dried form for long times. It is safe for all living things, and is used for manufacturing supplements and food. Saccharomyces cerevisiae is being successfully used as a model living cell, to solve and understand many biological processes that occur in the living cells of higher eukaryotes, including humans. S. cerevisiae metabolites can be used in treating some diseases such as immuno-compromised, respiratory or cardiovascular diseases [43]. However, its application as a biocatalyst in MFCs is limited because of the difficult electron transfer from its mitochondria to the outer cell membrane, and then to the anode surface. Because of this, most studies are using an external mediator to enhance the electron transfer from yeast cell to the anode of MFC, which is not preferable in large scale applications $[44,45]$.

The properties of the electrode's materials, i.e., anode and cathode, determine the cost and performance of the MFC. Due to its high surface area, biocompatibility, low cost, good electrical conductivity, and stability of carbon materials [46], it has been used extensively as the anode of MFCs. Different forms of carbon are used as the anode MFCs, including carbon paper, carbon cloth, carbon brush (CB), carbon rods, graphite felt and graphite granules. Different methodes used to improve the characteristics of carbon electrodes through surface treatment, such as: heat or acid 
treatment, the addition of nano-carbon materials, or metals on their surface [47-50]. Graphene is a two-dimensional carbon that exhibited promising features in energy conversion/storage devices [51-54]. The graphene-modified electrodes have demonstrated good performance in MFCs due to their extremely high surface area and high electron mobility $[55,56]$. However, their application is limited by their antibacterial properties that would negatively affect the performance of the MFC.

Several techniques are used to enhance the transfer of electrons in mediator-less yeast-based MFCs, including: enhancing the anode with thin cobalt film, promoting the growth of yeast cells and improving the transfer of electrons between the yeast cells and the modified carbon cloth (cobalt coated) [50]. Chemically treated carbon felt with polyethyleneimine resulted in a three times increase in the yeast-based MFC compared to the untreated one, due to the improved yeast cell attachments with [57] and without using mediators [58]. The fixing of yeast cells on the surface of carbon nanotubes was found to be an effective method for increasing the power output of yeast-based MFCs [59].

Carbon nitride $\left(\mathrm{C}_{3} \mathrm{~N}_{4}\right)$ is a well-known two-dimensional semiconductor material composed of carbon and nitrogen. Carbon nitride $\left(\mathrm{C}_{3} \mathrm{~N}_{4}\right)$ can be found in various allotropic forms, such as $\alpha$ $\mathrm{C}_{3} \mathrm{~N}_{4}, \beta-\mathrm{C}_{3} \mathrm{~N}_{4}$, and graphitic- $\mathrm{C}_{3} \mathrm{~N}_{4}\left(\mathrm{~g}-\mathrm{C}_{3} \mathrm{~N}_{4}\right), \mathrm{g}-\mathrm{C}_{3} \mathrm{~N}_{4}$ is a stable allotrope, with facile synthesis, it is chemically, and thermally stable at ambient conditions, has high nitrogen content, high surface area, is eco-friendly, and cheap [60]. $\mathrm{g}-\mathrm{C}_{3} \mathrm{~N}_{4}$ is a two-dimensional substance consisting of conjugated polymer structures with s-heptazine (tri-s-triazine) or s-triazine units linked to each other by tertiary amines $[61,62]$. This structure gives it unique physical and electronic characteristics, like ability to transport charge carriers. It is therefore, a good candidate in energy and environmental applications $[63,64]$. In addition, $\mathrm{g}-\mathrm{C}_{3} \mathrm{~N}_{4}$ is typically processed by thermal 
polycondensation of carbon-based precursors, such as cyanamide, dicyanamide, urea, thiourea, and melamine, which contain low-cost nitrogen [65]. Thus, g- $\mathrm{C}_{3} \mathrm{~N}_{4}$ is extensively used as a catalyst in many applications, i.e., sensors, photocatalyst, water-splitting, light-emitting devices, heavy metals ion sensors, and oxygen reduction reaction [65-67]. The main limitation of the $\mathrm{g}-\mathrm{C}_{3} \mathrm{~N}_{4}$ is its low electrical conductivity (semiconductor), which can be solved by preparing a composite of it with carbon [68].

Due to the biocompatibility and the above-mentioned characteristics of $\mathrm{g}-\mathrm{C}_{3} \mathrm{~N}_{4}$, it considered a suitable anode material for MFCs. To the best of the authors' knowledge, $\mathrm{g}-\mathrm{C}_{3} \mathrm{~N}_{4}$ has not yet been reported as an anode of any type of MFCs. In this study, the carbon brush anode was modified with g- $\mathrm{C}_{3} \mathrm{~N}_{4}$ through a facile and binder-free one-step preparation method. The composite electrode was used for the first time as an anode of yeast-based MFC, and its performance was compared to that of a bare carbon brush.

\section{Materials and methods}

\subsection{Synthesis of graphitic carbon nitride/ carbon fiber brush composite $\left(\mathrm{g}-\mathrm{C}_{3} \mathrm{~N}_{4} @ \mathrm{CB}\right)$}

Two carbon fiber brushes, from Alfa Aesar Chemicals Company, USA, with a $4 \mathrm{~cm}$ length and 3 $\mathrm{cm}$ diameter, were cleaned in an ultrasonic bath in $0.1 \mathrm{M} \mathrm{HCl}$, acetone, and deionized water, for 15 minutes each. One of the cleaned electrodes was immersed in urea powder in an alumina crucible, that was covered with aluminum foil and then inserted in an oven under static air conditions at $550^{\circ} \mathrm{C}$ for 4 hours. After cooling down, the brush was cleaned of the white-yellowish surrounding powder $\left(\mathrm{g}-\mathrm{C}_{3} \mathrm{~N}_{4}\right)$, and the cleaned brush was named as g- $\mathrm{C}_{3} \mathrm{~N}_{4} @ \mathrm{CB}$.

\subsection{Yeast cultivation}


A dried yeast "Saccharomyces cerevisiae, S.I. Lesa ffre, Marcq-en-Baroeul, France" of $0.13 \mathrm{~g}$ was cultivated in $100 \mathrm{ml}$ distilled water containing $1 \mathrm{~g}$ yeast extract, $2 \mathrm{~g}$ peptone, and $0.5 \mathrm{~g}$ glucose at $30^{\circ} \mathrm{C}$ for $16 \mathrm{~h}$.

\subsection{Microbial Fuel cell}

A cylindrical air cathode MFC consisting of a $23 \mathrm{ml}$ cylindrical anode chamber $(3 \mathrm{~cm}$ diameter and $3.5 \mathrm{~cm}$ length) was used in this study. The anolyte was prepared by adding $3 \mathrm{ml}$ of cultivated yeast and glucose $(20 \mathrm{~g} / \mathrm{L})$ in a $20 \mathrm{ml}$ phosphate buffer of $50 \mathrm{mM}$. A ready-made cathode of 3.4 $\mathrm{cm}^{2}$ of carbon cloth with Pt catalyst of $0.5 \mathrm{mg} / \mathrm{cm}^{2}$ loading from EC-20-10, ElectroChem, Inc., and Nafion 117 as the membrane. Two MFCs were constructed in parallel, one of them using plain carbon brush $(\mathrm{CB})$ and the other one using $\mathrm{g}-\mathrm{C}_{3} \mathrm{~N}_{4} @ \mathrm{CB}$. Saturated $\mathrm{Ag} / \mathrm{AgCl}$ electrode was immersed in the anode chamber to record the anode potentials. All chemicals, urea, glucose, yeast extract, peptone, and phosphate buffer were supplied from Sigma-Aldrich.

\subsection{Characterization of the synthesized composite.}

The crystalline structure and surface functional groups of the $\mathrm{CB}$ and g- $\mathrm{C}_{3} \mathrm{~N}_{4} @ \mathrm{CB}$ were performed using XRD (TESCAN VEGA3, Bruker D8) and FTIR-6300, JASCO, respectively. The surface morphology and elemental analysis of the $\mathrm{CB}$, and $\mathrm{g}-\mathrm{C}_{3} \mathrm{~N}_{4} @ \mathrm{CB}$ were performed using SEM "scanning electron microscope", equipped with EDX “Tescan VEGA $\alpha$ XMU”. The electrodes at the end of the MFC operation were dried in an oven at $50{ }^{\circ} \mathrm{C}$ for 12 hours, before investigating the biofilm formation using SEM.

\subsection{Electrochemical measurements:}

The two MFCs were operated at $25{ }^{\circ} \mathrm{C}$. The open-circuit voltage (OCV) of the two cells and the anode potentials vs. $\mathrm{Ag} / \mathrm{AgCl}$ were recorded using a data logger "Graphtec midi LOGGER GL 
240". The cell circuit was closed after the OCVs and the anode potentials reached steady state, and polarization measurements from $\mathrm{OCV}$ to $0 \mathrm{~V}$ were performed at $1 \mathrm{mV} / \mathrm{s}$. The current discharge with time at $0.2 \mathrm{~V}$ was also measured. Between $100 \mathrm{kHz}$ to $100 \mathrm{mHz}$, the EIS "electrochemical impedance spectroscopy" for the two MFCs was conducted at $0.2 \mathrm{~V}$. All electrochemical measurements were performed using a Biologic "VSP-200".

\section{Results and discussion}

3.1 Surface morphology and crystalline structure of $\mathrm{CB}$ and g- $\mathrm{C}_{3} \mathrm{~N}_{4} @ \mathrm{CB}$.

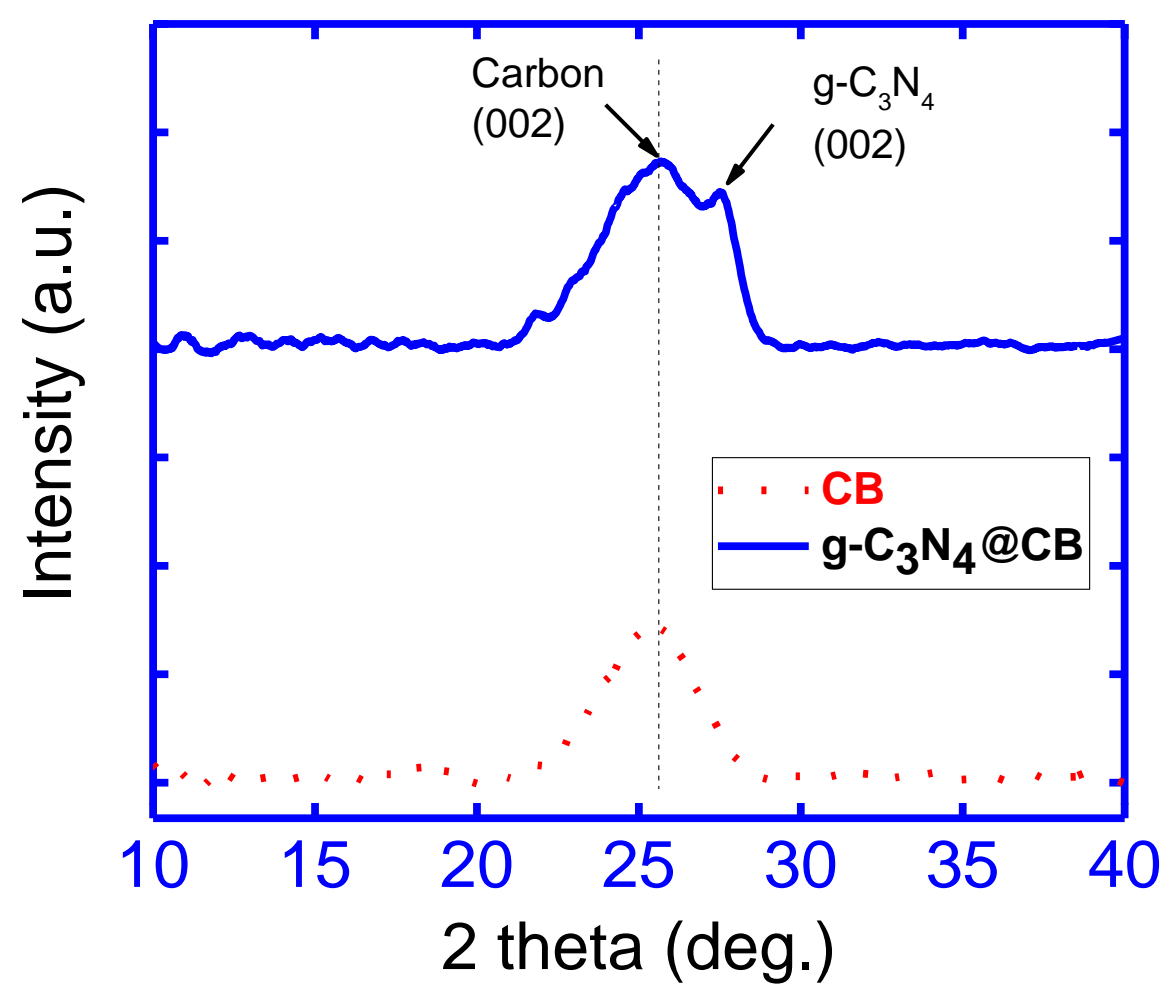

Fig. 1: XRD of the carbon brush fibers $(\mathrm{CB})$ and $\mathrm{g}-\mathrm{C}_{3} \mathrm{~N}_{4} @ \mathrm{CB}$

The XRD of the bare CB fibers and the composite of the $\mathrm{C}_{3} \mathrm{~N}_{4} @ \mathrm{CB}$ are shown in Figure 1. It is clear from the figure that there is a broad peak at around $2 \theta$ of $25^{\circ}$, which corresponds to 002 
amorphous carbon of the $\mathrm{CB}$. In the case of the g- $\mathrm{C}_{3} \mathrm{~N}_{4} @ \mathrm{CB}$, an additional peak appeared at $2 \theta$ of $27.2^{\circ}$, which corresponds to (002) of $\mathrm{g}-\mathrm{C}_{3} \mathrm{~N}_{4}$ [69]. The overlapping of the two peaks indicates the formation of the composite of the $\mathrm{g}-\mathrm{C}_{3} \mathrm{~N}_{4}$ and the carbon of the $\mathrm{CB}$ fibers.

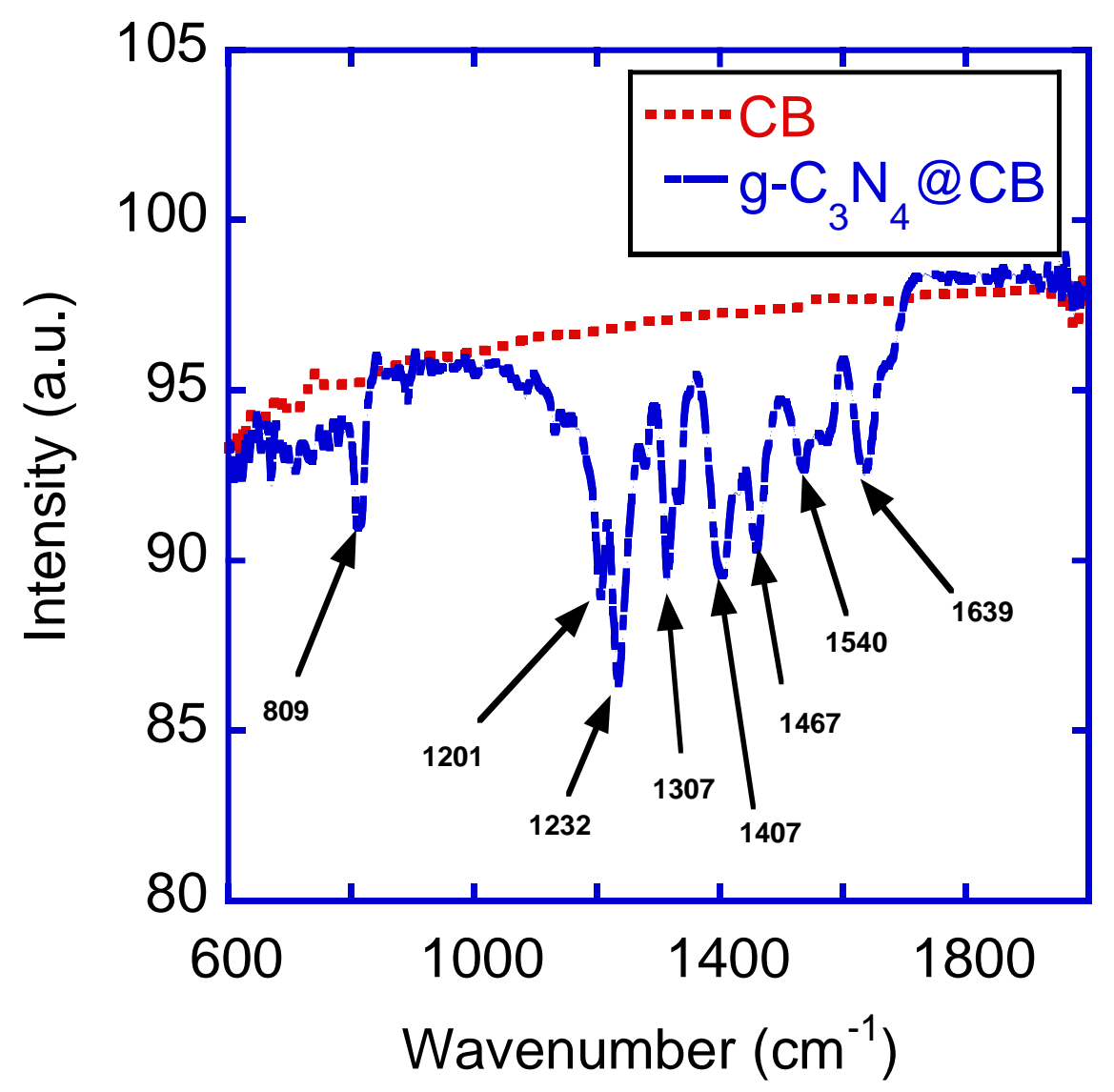

Fig. 2: FTIR of the bare CB fibers and g- $\mathrm{C}_{3} \mathrm{~N}_{4} @ \mathrm{CB}$.

There are no functional groups detected on the surface of the bare $\mathrm{CB}$, while in the case of the g$\mathrm{C}_{3} \mathrm{~N}_{4} @ \mathrm{CB}$, several functional groups are detected, Fig. 2. A peak at $809 \mathrm{~cm}^{-1}$ indicates a triazine ring; peaks at $1232 \mathrm{~cm}^{-1}, 1307 \mathrm{~cm}^{-1}$, and at $1407 \mathrm{~cm}^{-1}$ indicate the aromatic $\mathrm{C}-\mathrm{N}$ stretching; and 
those at $1540 \mathrm{~cm}^{-1}$ and $1639 \mathrm{~cm}^{-1}$ relate to $\mathrm{C}=\mathrm{N}$ stretching $[70,71]$. These results are consistent with those of XRD, Fig. 1. 

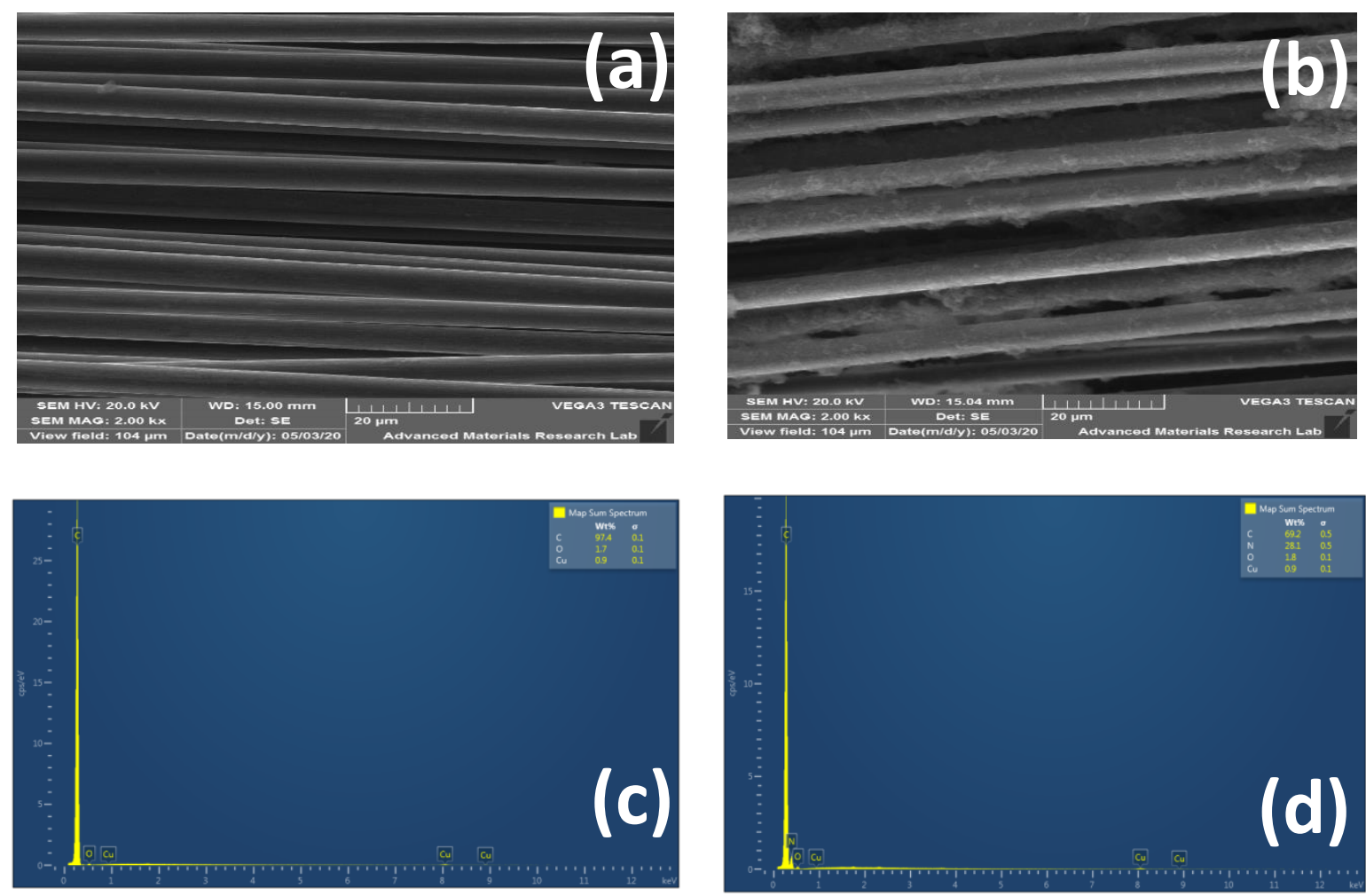

C K $\alpha 12$

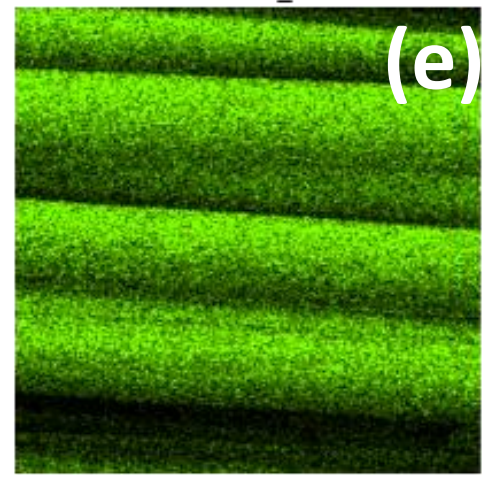

C Ka1_2

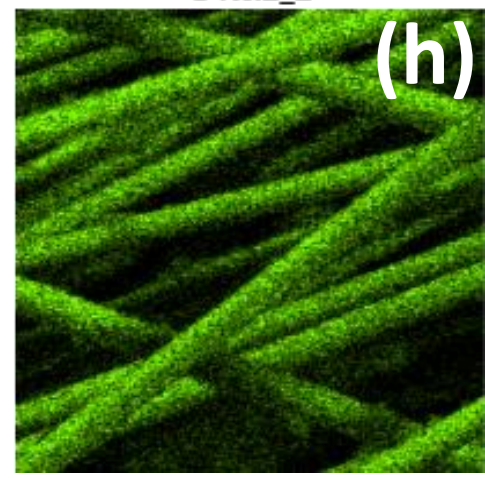

$\mathrm{O} K \alpha 1$

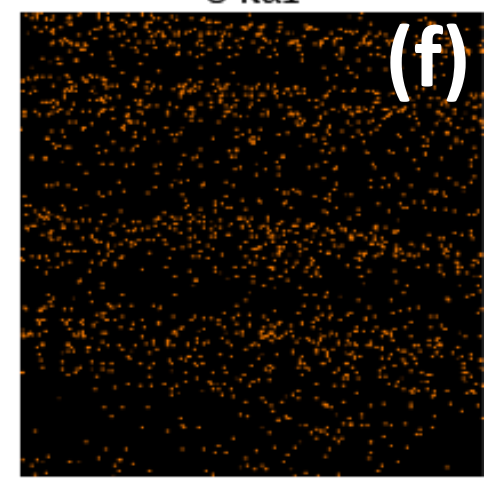

$\mathrm{O} K \alpha 1$

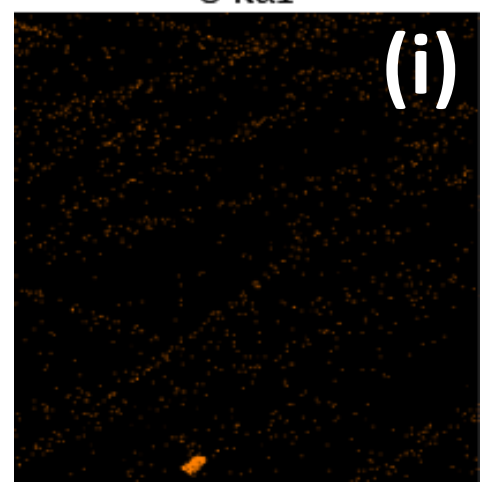

$\mathrm{Cu} K \alpha 1$

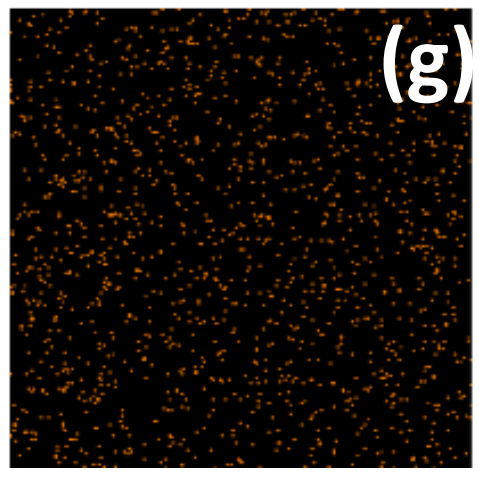

N K $\alpha 12$

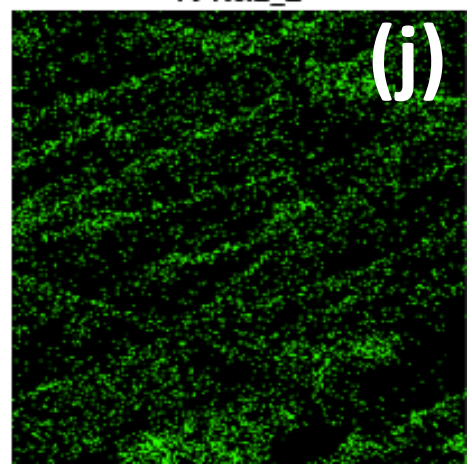

Fig.3: SEM images of CB (a) and g- $\mathrm{C}_{3} \mathrm{~N}_{4} @ \mathrm{CB}$ (b), Elemental analysis of CB (c) and g- $\mathrm{C}_{3} \mathrm{~N}_{4} @ \mathrm{CB}$ (d), elemental mapping of CB (e-g), and g- $\mathrm{C}_{3} \mathrm{~N}_{4} @ \mathrm{CB}(\mathrm{h}-\mathrm{j})$. 
The morphology of the surface and elemental composition of the bare $\mathrm{CB}$ and $\mathrm{g}-\mathrm{C}_{3} \mathrm{~N}_{4} @ \mathrm{CB}$ are shown in Figure 3. As evident in the figure, the $\mathrm{CB}$ is made up of smooth fibers of around $5 \mu \mathrm{m}$ in diameter. The elemental analysis of CB shown in Fig. 3c demonstrated that the fibers are mainly composed of carbon, $97.4 \mathrm{wt} \%$, with traces of adsorbed surface oxygen, 1.7wt \%. Fig. 3(e-g) shows the elemental mapping of the $\mathrm{CB}$ fibers with different elements, $\mathrm{C}, \mathrm{N}$, and $\mathrm{Cu}$. The $\mathrm{Cu}$ that appeared is for the tape used for fixing the CB fibers. The SEM images of the $\mathrm{g}-\mathrm{C}_{3} \mathrm{~N}_{4} @ \mathrm{CB}$, Fig. $3 b$, show a rough surface of the fibers compared to those of the bare CB. The elemental composition, Fig. 3d, demonstrated a high percentage of nitrogen of $29 \mathrm{wt} \%$, as well as $69 \mathrm{wt} \%$ of carbon. There were also other traces of adsorbed oxygen and $\mathrm{Cu}$ (not shown here). The appearance of the well-dispered high percentages of nitrogen on the entire surface of the $g-\mathrm{C}_{3} \mathrm{~N}_{4} @ \mathrm{CB}$ fibers can be credited to the chemical composition of the $\mathrm{g}-\mathrm{C}_{3} \mathrm{~N}_{4}$ formed on the $\mathrm{CB}$ surface during the heat treatment of the $\mathrm{CB}$ in urea in thse oven. These results confirm the formation of the $\mathrm{g}-\mathrm{C}_{3} \mathrm{~N}_{4}$, that is in accordance to the XRD results (Fig. 1) and FTIR results (Fig.2).

\subsection{Electrochemical behavior of the $\mathrm{CB}$ and $\mathrm{g}-\mathrm{C}_{3} \mathrm{~N}_{4} @ \mathrm{CB}$ under actual MFC operation.}

\subsubsection{Yeast-based MFC under open circuit condition}

Two MFCs with plain $\mathrm{CB}$ and g- $\mathrm{C}_{3} \mathrm{~N}_{4} @ \mathrm{CB}$ anodes were investigated under OCV, where the OCV and anode potentials were recorded with time until they reached a plateau, as shown in Fig. 4 . The OCV of the two cells gradually increased within 5 hours until they reached steady values of 0.63 and $0.77 \mathrm{~V}$ for the $\mathrm{MFC}$ with $\mathrm{CB}$ and $\mathrm{g}-\mathrm{C}_{3} \mathrm{~N}_{4} @ \mathrm{CB}$ anodes, respectively, Fig. 4a. As the cathode potential was almost the same, the decrease in the anode potential would be the main reason for increasing in the OCV of the MFCs. Fig. $4 \mathrm{~b}$ shows the variation of the anode potentials of the two MFCs using $\mathrm{CB}$ and $\mathrm{g}-\mathrm{C}_{3} \mathrm{~N}_{4} @ \mathrm{CB}$ anodes. The anode potential of the MFC using the $\mathrm{CB}$ began at $0.13 \mathrm{~V}$ "vs. Ag / AgCl", and progressively decreased due to the anode surface attachment of the 
yeast cells and the glucose metabolism by yeast cells [32]. This occurred until it reached a steady value of $-0.1 \mathrm{~V}$ "vs. $\mathrm{Ag} / \mathrm{AgCl}$ ”. Meanwhile, the anode potential of the $\mathrm{g}-\mathrm{C}_{3} \mathrm{~N}_{4} @ \mathrm{CB}$ reached to $0.27 \mathrm{~V}$ “vs. Ag/AgCl”, Fig. 4b.
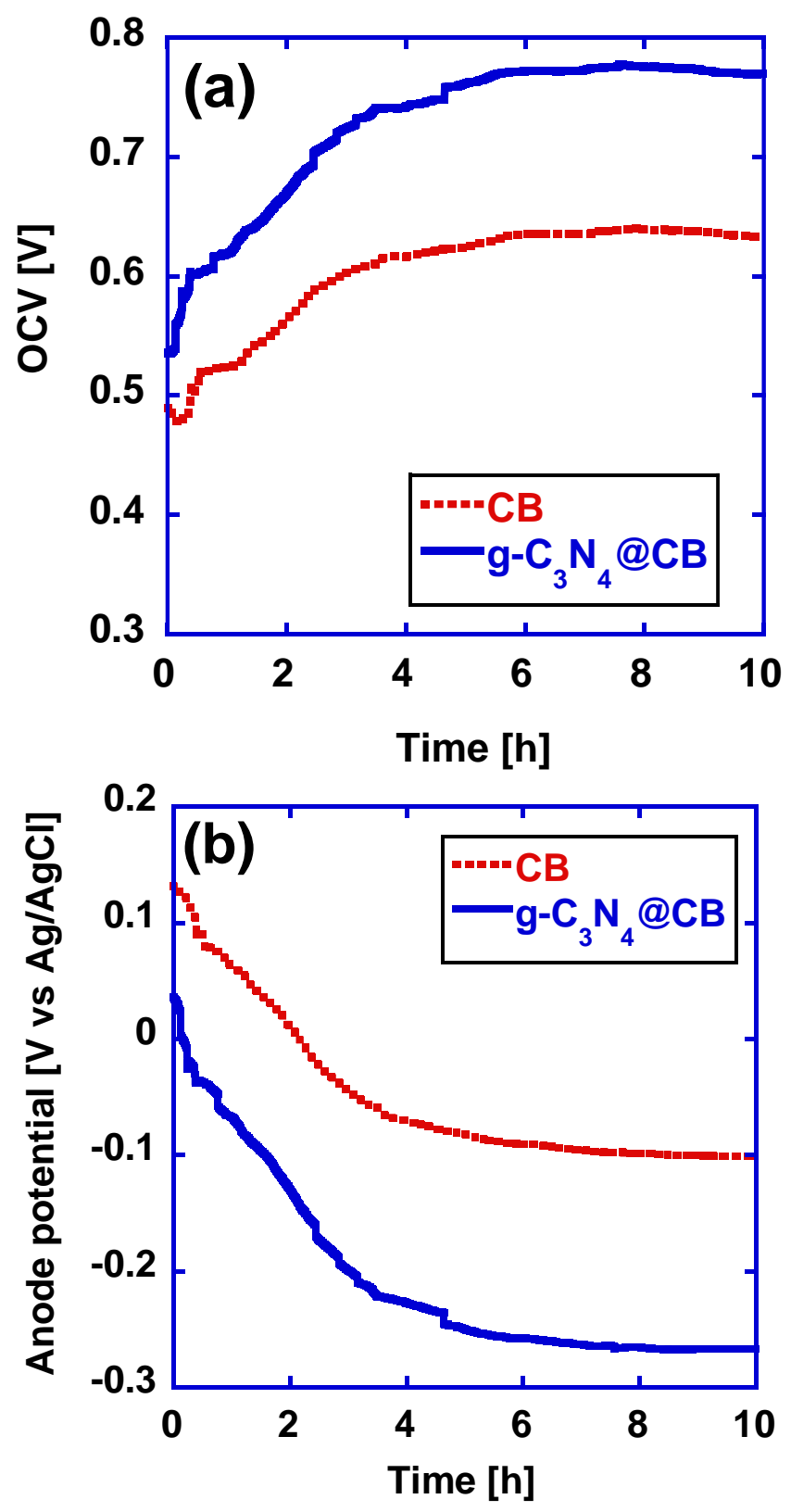

Fig.4: (a) the variation in the OCV, and (b) the anode potential of the two MFCs using CB and g$\mathrm{C}_{3} \mathrm{~N}_{4} @ \mathrm{CB}$ anodes. 


\subsubsection{Yeast-based MFC under actual cell operation}

The MFC cells with $\mathrm{CB}$ and $\mathrm{g}-\mathrm{C}_{3} \mathrm{~N}_{4} @ \mathrm{CB}$ anodes were operated under closed-circuit conditions, and the polarization measurement was conducted. Figure 5 shows the current voltage and current power curves for the two cells using the $\mathrm{CB}$ and the $\mathrm{g}-\mathrm{C}_{3} \mathrm{~N}_{4} @ \mathrm{CB}$ anodes. As can be seen in the figure, the yeast-based MFC using the CB anode achieved a maximum current density of 330 $\mathrm{mA} / \mathrm{m}^{2}$ and a maximum power of $60 \mathrm{~mW} / \mathrm{m}^{2}$, compared to $2,200 \mathrm{~mA} / \mathrm{m}^{2}$ and $770 \mathrm{~mW} / \mathrm{m}^{2}$, respectively, in case of the $\mathrm{g}-\mathrm{C}_{3} \mathrm{~N}_{4} @ \mathrm{CB}$ anode. This result demonstrates the outstanding performance of $\mathrm{g}-\mathrm{C}_{3} \mathrm{~N}_{4} @ \mathrm{CB}$ anodes, with a twelve time higher power output compared to the $\mathrm{CB}$ anode. It is also evident that the limiting current occurs at $0.3 \mathrm{~V}$, and lower cell voltages are seen in the case of the improved electrode.

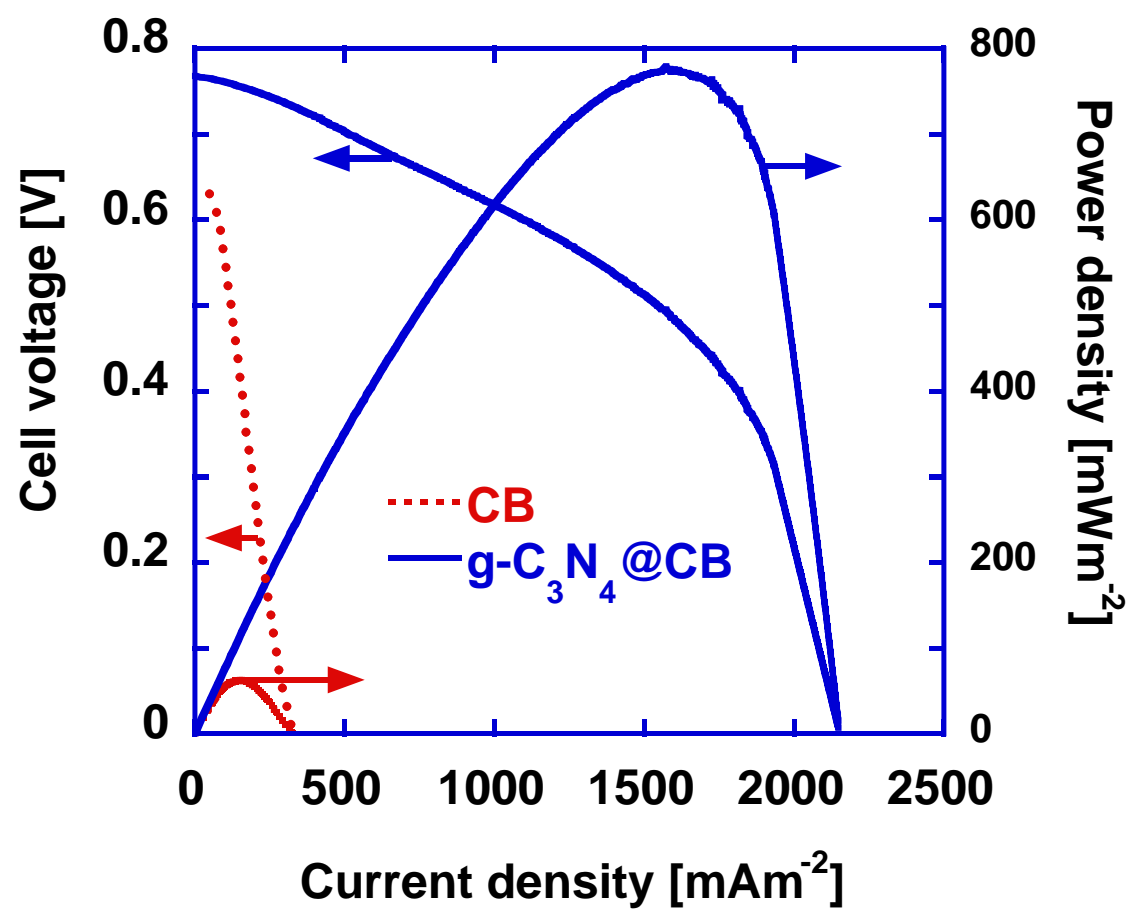


Fig.5: Current voltages and current power relationships of the two cells using CB and g$\mathrm{C}_{3} \mathrm{~N}_{4} @ \mathrm{CB}$ anodes.

Where the i-V measurement shows spontaneous behavior of the cell, it is better to investigate cell performance for a longer time period. Figure 6 clears the discharged current of the two cells operated for five hours at $0.2 \mathrm{~V}$. In the case of the MFC using the CB, the current density started at around $300 \mathrm{mAm}^{-2}$ and rapidly decreased during the first few minutes to $115 \mathrm{mAm}^{-2}$, and then to $40 \mathrm{mAm}^{-2}$ after $30 \mathrm{~min}$. It then slightly decreased within the next 4 hours of cell operation to 30 $\mathrm{mAm}^{-2}$. While, in case of the MFC using the $\mathrm{g}-\mathrm{C}_{3} \mathrm{~N}_{4} @ \mathrm{CB}$ electrode, the current density started at around 3,300 $\mathrm{mAm}^{-2}$, and rapidly decreased to $1,800 \mathrm{mAm}^{-2}$. It then reached $150 \mathrm{mAm}^{-2}$ after 30 min, then reached a steady-state current of $90 \mathrm{mAm}^{-2}$ after 5 hours of cell operation. The rapid decrease in the current densities of the two cells would is due to the rapid depletion of the negative charge, i.e., electrons that formed on the anode surfaces before operating the cells.

The authors already reported that the electron transfer in the Saccharomyces cerevisiae based MFC takes place through direct contact between the outer yeast cell membrane and the anode surface, therefore, the biofilm plays significant role in the performance [32]. To understand the reason for the improved cell performance in case of $\mathrm{g}-\mathrm{C}_{3} \mathrm{~N}_{4} @ \mathrm{CB}$ anode, the surface morphology of the two electrodes was investigated at the end of the cell operation, as shown in Fig. 7. 


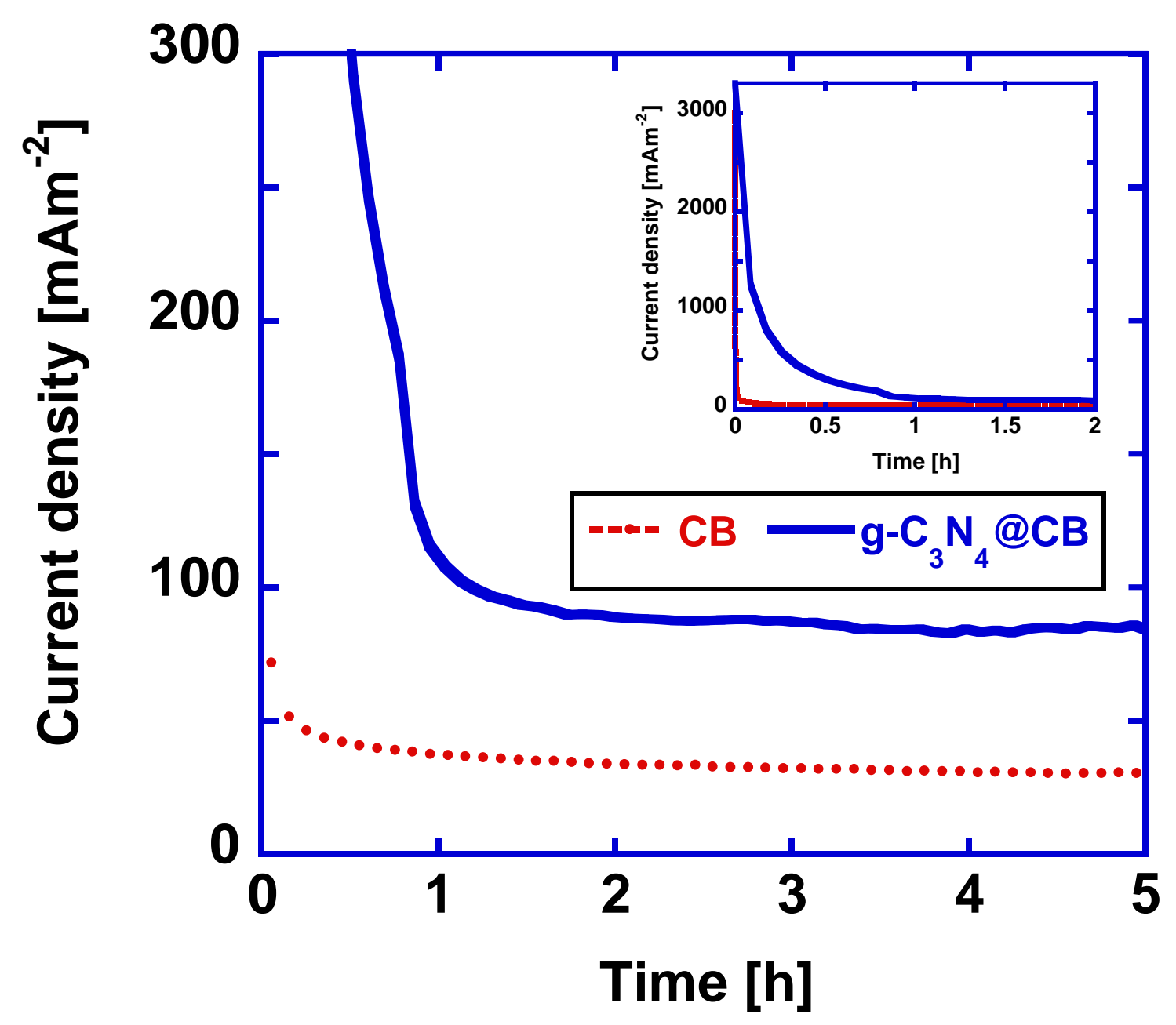

Fig.6: Chronoamperometry @ $0.2 \mathrm{~V}$ of the two cells using $\mathrm{CB}$ and g- $\mathrm{C}_{3} \mathrm{~N}_{4} / \mathrm{CB}$ anodes.

As seen in the figure, a few yeast cells were detected on the surface of the CB, Fig. $7 \mathrm{a}$ and $7 \mathrm{~b}$. A thick biofilm was detected at the modified electrode's surface. The dense biofilm formed using g$\mathrm{C}_{3} \mathrm{~N}_{4} @ \mathrm{CB}$ anode is related to the biocompatibility of the $\mathrm{g}-\mathrm{C}_{3} \mathrm{~N}_{4}$ and the rough surface of the $\mathrm{c}$ electrode (Fig. 3b). The high biocompatibility between the two is evident from the growth of the yeast cells within the $\mathrm{g}-\mathrm{C}_{3} \mathrm{~N}_{4}$ layer formed on the surface of the $\mathrm{CB}$ fibres. 

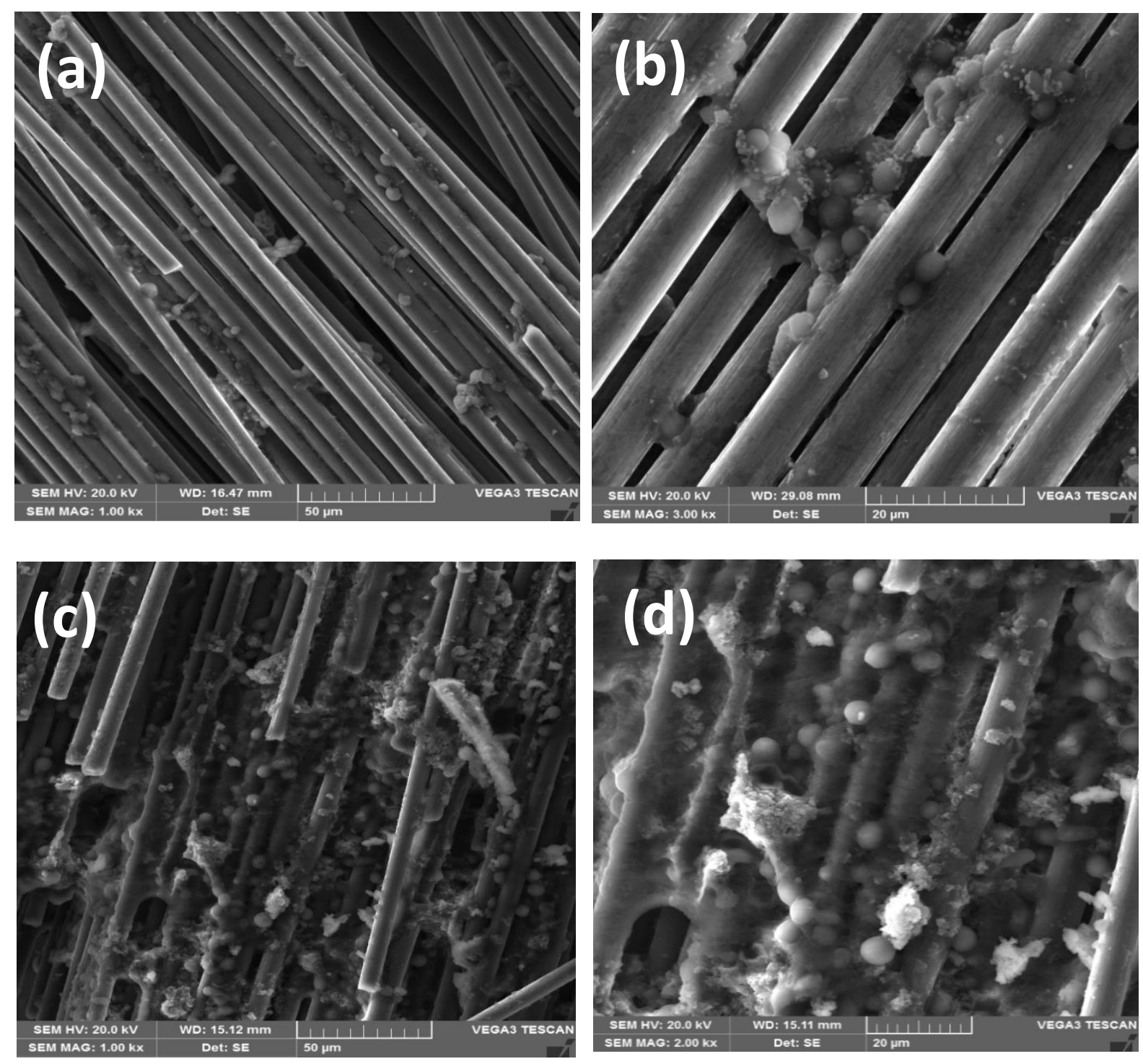

Fig. 7: SEM images of the different anodes at the end of the cell operation using: (a and b) CB, and (c and d) g- $\mathrm{C}_{3} \mathrm{~N}_{4} @ \mathrm{CB}$.

EIS was used to determine the effect of g- $\mathrm{C}_{3} \mathrm{~N}_{4} @ \mathrm{CB}$ on the electron transfer from the yeast cells and the anode surface, as shown in figure 8 . The intersection between the impedance spectra at high frequency with the $\mathrm{x}$-axis gave an indication for the ohmic resistance, while the diameter of the semi circuit spectra at medium frequency showed the charge transfer resistivity [72]. The figure shows that, in the case of $\mathrm{g}-\mathrm{C}_{3} \mathrm{~N}_{4} @ \mathrm{CB}$, the ohmic resistance, was around $45 \Omega$ compared to 57 
$\Omega$ in the case of the bare $\mathrm{CB}$ anode. Moreover, the $\mathrm{g}-\mathrm{C}_{3} \mathrm{~N}_{4} @ \mathrm{CB}$ anode enhanced the charge transfer, as can be seen in the smaller semi circuit spectra at medium frequency. Therefore, it could be concluded that the improved performance in the case of the g- $\mathrm{C}_{3} \mathrm{~N}_{4} @ \mathrm{CB}$ anode is related to the enhancement of the biofilm growth, as well as the easy charge transfer between the yeast cells and the modified electrode.

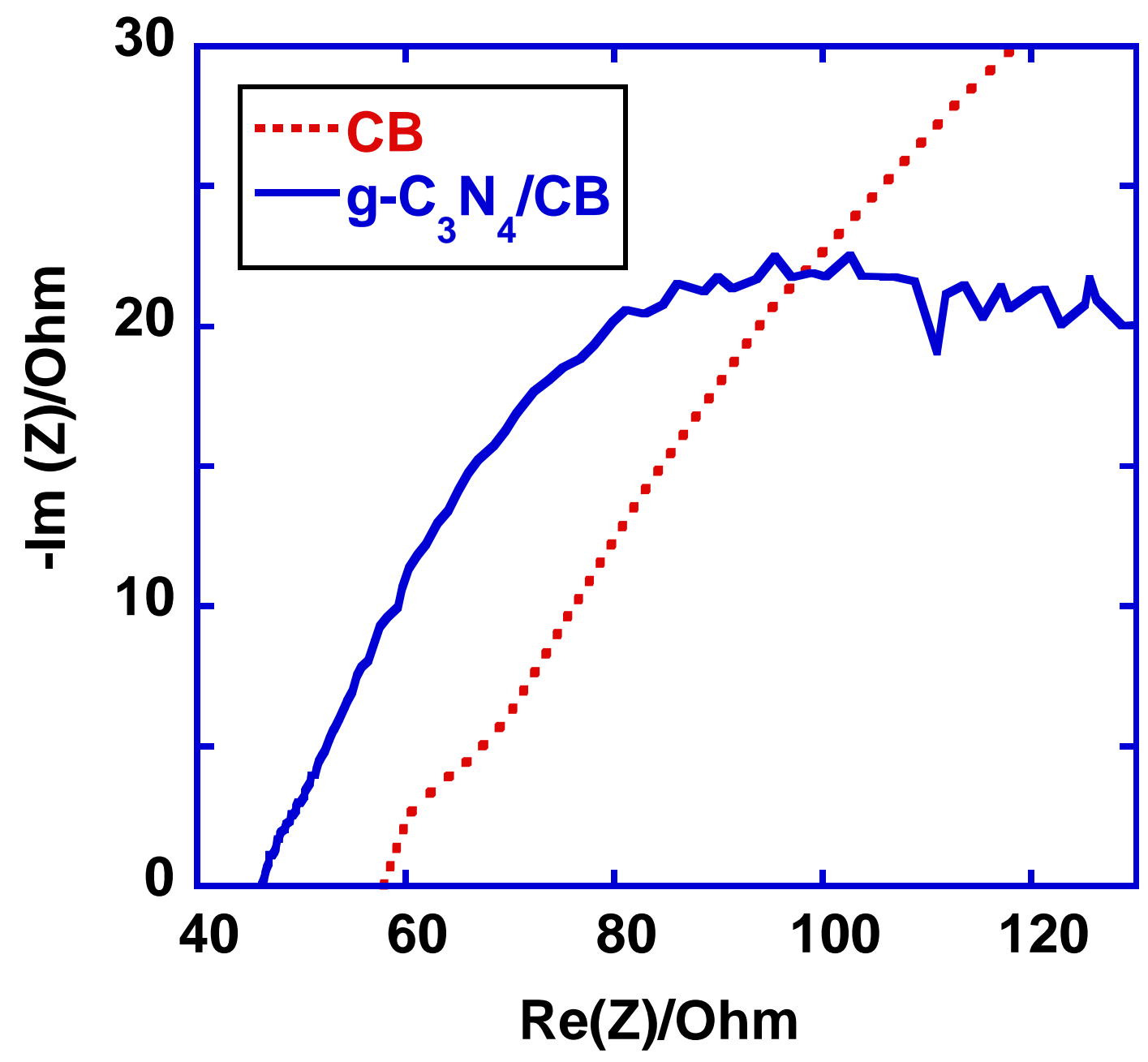

Fig. 8: Electrochemical impedance spectroscopy (EIS) of the MFCs with $\mathrm{CB}$ and $\mathrm{g}-\mathrm{C}_{3} \mathrm{~N}_{4} @ \mathrm{CB}$. 
The obtained results in this study were compared to other reported results of yeast

based-MFC using different modifications of the anode. As can be seen in Table 1, the results of the current study are the highest reported values for a single-chamber cell design. This work will pave ways for further studies of $\mathrm{g}_{-} \mathrm{C}_{3} \mathrm{~N}_{4}$ in different bioelectrochemical devices.

Table 1: Comparison of g- $\mathrm{C}_{3} \mathrm{~N}_{4} @ \mathrm{CB}$ anode with other studies performed using different anode modification in mediatorless yeast-based MFCs.

\begin{tabular}{|c|c|c|c|c|c|c|c|c|}
\hline $\begin{array}{l}\text { Yeast } \\
\text { strain }\end{array}$ & $\begin{array}{l}\text { MFC } \\
\text { type }\end{array}$ & Substrate & $\begin{array}{l}\text { Anolyte } \\
\text { Vol. (ml) }\end{array}$ & Modified anode & separator & cathode & $\begin{array}{l}\text { Relative } \\
\text { increase in } \\
\text { MPD }(\%)\end{array}$ & Ref. \\
\hline \multirow{8}{*}{$\begin{array}{l}S . \\
\text { cerevisiae }\end{array}$} & \multirow{5}{*}{$\begin{array}{l}\text { Single } \\
\text { chamber }\end{array}$} & \multirow{8}{*}{ Glucose } & 70 & $\begin{array}{c}\text { Carbon paper } \\
\text { sputtered with } 30 \\
\text { nm layer of } \mathrm{Co}\end{array}$ & \multirow{5}{*}{$\begin{array}{c}\text { Nafion } \\
117\end{array}$} & $\begin{array}{l}\text { Pt/Carbon } \\
\text { paper }\end{array}$ & $56.6 \%$ & {$[50]$} \\
\hline & & & \multirow{2}{*}{28} & $\begin{array}{l}\text { Carbon felt } \\
\text { polyethyleneimine } \\
\text { /Phenylethano }\end{array}$ & & \multirow{3}{*}{ Carbon felt } & $10.5 \%$ & \multirow[t]{2}{*}[73]{} \\
\hline & & & & $\begin{array}{c}\text { Carbon felt } \\
\text { polyethyleneimine } \\
\text { /Tryptophol }\end{array}$ & & & $8.5 \%$ & \\
\hline & & & 128 & $\begin{array}{c}\text { Carbon felt } \\
\text { polyethyleneimine/ } \\
\text { gold nanoparticles }\end{array}$ & & & $627.3 \%$ & {$[74]$} \\
\hline & & & 25 & $\begin{array}{c}\text { Carbon brush/g- } \\
\text { C3N4 }\end{array}$ & & $\begin{array}{l}\mathrm{Pt} / \text { Carbon } \\
\text { cloth }\end{array}$ & $1186.7 \%$ & $\begin{array}{l}\text { This } \\
\text { study }\end{array}$ \\
\hline & \multirow{3}{*}{$\begin{array}{c}\text { Two } \\
\text { chambers }\end{array}$} & & \multirow{2}{*}{128} & Carbon felt/HNO3 & \multirow{2}{*}{$\begin{array}{l}\text { CEM } \\
\text { (CMI } \\
7000) \\
\end{array}$} & \multirow{2}{*}{$\begin{array}{c}\text { Carbon } \\
\text { paper }\end{array}$} & $150 \%$ & \multirow{2}{*}[75]{} \\
\hline & & & & Carbon felt/PANI & & & $190 \%$ & \\
\hline & & & 50 & $\begin{array}{c}\text { Carbon felt/ } \\
\text { polyethyleneimine }\end{array}$ & \multirow{4}{*}{$\begin{array}{l}\text { Nation } \\
117\end{array}$} & \multirow{4}{*}{ Carbon felt } & $108.3 \%$ & {$[58]$} \\
\hline \multirow{3}{*}{$\begin{array}{l}\text { C. } \\
\text { melibiosica }\end{array}$} & \multirow{3}{*}{$\begin{array}{c}\text { Two } \\
\text { chambers }\end{array}$} & \multirow{3}{*}{ Fructose } & \multirow{3}{*}{13} & Carbon felt/ NiFeP & & & $400 \%$ & \multirow{2}{*}{ [76] } \\
\hline & & & & Carbon felt/ NiFe & & & $80 \%$ & \\
\hline & & & & Carbon felt/Ni & & & $1900 \%$ & [77] \\
\hline
\end{tabular}




\section{Conclusions}

A composite of $\mathrm{g}-\mathrm{C}_{3} \mathrm{~N}_{4}$ and the fibers of carbon brush was successfully prepared using a facile one-step preparation method. The composite electrode was investigated for the first time in a mediatorless, yeast-based MFC. The results demonstrated superior performance of the modified electrode, which exhibited a twelve time higher maximum power output compared to that of the bare $\mathrm{CB}$ anode. The improved performance was attributed to the large quantity of biofilm formed due to the rough surface and biocompatibility of the modified electrode and, as verified by the EIS measurements, because of the enhanced charge. This lays the groundwork for $\mathrm{g}_{-} \mathrm{C}_{3} \mathrm{~N}_{4} @ \mathrm{CB}$ to be applied in various bio-electrochemical cells, such as microbial electrolysis and microbial desalination cells.

\section{References}

[1] Stolarski MJ, Warmiński K, Krzyżaniak M, Olba-Zięty E, Stachowicz P. Energy consumption and heating costs for a detached house over a 12-year period - Renewable fuels versus fossil fuels. Energy. 2020;204:117952.

[2] Hanif I, Faraz Raza SM, Gago-de-Santos P, Abbas Q. Fossil fuels, foreign direct investment, and economic growth have triggered $\mathrm{CO} 2$ emissions in emerging Asian economies: Some empirical evidence. Energy. 2019;171:493-501.

[3] Elsaid K, Sayed ET, Abdelkareem MA, Baroutaji A, Olabi AG. Environmental impact of desalination processes: Mitigation and control strategies. Science of The Total Environment. 2020;740:140125.

[4] Elsaid K, Sayed ET, Abdelkareem MA, Mahmoud MS, Ramadan M, Olabi AG. Environmental impact of emerging desalination technologies: A preliminary evaluation. Journal of Environmental Chemical Engineering. 2020;8(5):104099.

[5] Olabi AG, Wilberforce T, Abdelkareem MA. Fuel cell application in the automotive industry and future perspective. Energy. 2020:118955.

[6] Liu L, Wu J, Zhong F, Gao N, Cui G. Development of a novel cogeneration system by combing organic rankine cycle and heat pump cycle for waste heat recovery. Energy. 2021;217:119445.

[7] Zhuang Y, Zhou C, Dong Y, Du J, Shen S. A hierarchical optimization and design of double Kalina Cycles for waste heat recovery. Energy. 2021;219:119593.

[8] Elsaid K, Taha Sayed E, Yousef BAA, Kamal Hussien Rabaia M, Ali Abdelkareem M, Olabi AG. Recent progress on the utilization of waste heat for desalination: A review. Energy Conversion and Management. 2020;221:113105.

[9] Olabi AG, Elsaid K, Rabaia MKH, Askalany AA, Abdelkareem MA. Waste heat-driven desalination systems: Perspective. Energy. 2020:118373. 
[10] Li T, Li A, Guo X. The sustainable development-oriented development and utilization of renewable energy industry--A comprehensive analysis of MCDM methods. Energy. 2020;212:118694.

[11] Abdelkareem MA, Assad MEH, Sayed ET, Soudan B. Recent progress in the use of renewable energy sources to power water desalination plants. Desalination. 2018;435:97-113.

[12] Yousef BAA, Rezk H, Abdelkareem MA, Olabi AG, Nassef AM. Fuzzy modeling and particle swarm optimization for determining the optimal operating parameters to enhance the bio-methanol production from sugar cane bagasse. International Journal of Energy Research.n/a(n/a).

[13] Liu R, Liu M, Zhao Y, Ma Y, Yan J. Thermodynamic study of a novel lignite poly-generation system driven by solar energy. Energy. 2021;214:119075.

[14] Rezk H, Sayed ET, Al-Dhaifallah M, Obaid M, El-Sayed AHM, Abdelkareem MA, et al. Fuel cell as an effective energy storage in reverse osmosis desalination plant powered by photovoltaic system. Energy. 2019;175:423-33.

[15] Laib I, Hamidat A, Haddadi M, Ramzan N, Olabi AG. Study and simulation of the energy performances of a grid-connected PV system supplying a residential house in north of Algeria. Energy. 2018;152:445-54.

[16] Wang Z, Bui Q, Zhang B. The relationship between biomass energy consumption and human development: Empirical evidence from BRICS countries. Energy. 2020;194:116906.

[17] Inayat A, Nassef AM, Rezk H, Sayed ET, Abdelkareem MA, Olabi AG. Fuzzy modeling and parameters optimization for the enhancement of biodiesel production from waste frying oil over montmorillonite clay K-30. Science of The Total Environment. 2019;666:821-7.

[18] Rodriguez C, Alaswad A, El-Hassan Z, Olabi AG. Waste paper and macroalgae co-digestion effect on methane production. Energy. 2018;154:119-25.

[19] Dalla Longa F, Nogueira LP, Limberger J, Wees J-Dv, van der Zwaan B. Scenarios for geothermal energy deployment in Europe. Energy. 2020;206:118060.

[20] Temiz M, Dincer I. Concentrated solar driven thermochemical hydrogen production plant with thermal energy storage and geothermal systems. Energy. 2021;219:119554.

[21] Wilberforce T, El Hassan Z, Durrant A, Thompson J, Soudan B, Olabi AG. Overview of ocean power technology. Energy. 2019;175:165-81.

[22] Sun Z, Zhang H, Liu X, Ding J, Xu D, Cai Z. Wave energy assessment of the Xisha Group Islands zone for the period 2010-2019. Energy. 2021;220:119721.

[23] Mahmoud M, Ramadan M, Olabi A-G, Pullen K, Naher S. A review of mechanical energy storage systems combined with wind and solar applications. Energy Conversion and Management.

2020;210:112670.

[24] Siddique MB, Thakur J. Assessment of curtailed wind energy potential for off-grid applications through mobile battery storage. Energy. 2020;201:117601.

[25] Sayed ET, Eisa T, Mohamed HO, Abdelkareem MA, Allagui A, Alawadhi H, et al. Direct urea fuel cells: Challenges and opportunities. Journal of Power Sources. 2019;417:159-75.

[26] He L, Du P, Chen Y, Lu H, Cheng X, Chang B, et al. Advances in microbial fuel cells for wastewater treatment. Renewable and Sustainable Energy Reviews. 2017;71:388-403.

[27] Abdelkareem MA, Sayed ET, Mohamed HO, Obaid M, Rezk H, Chae K-J. Nonprecious anodic catalysts for low-molecular-hydrocarbon fuel cells: Theoretical consideration and current progress. Progress in Energy and Combustion Science. 2020;77:100805.

[28] Abdelkareem MA, Tanveer WH, Sayed ET, Assad MEH, Allagui A, Cha SW. On the technical challenges affecting the performance of direct internal reforming biogas solid oxide fuel cells. Renewable and Sustainable Energy Reviews. 2019;101:361-75.

[29] Abdelkareem MA, Allagui A, Sayed ET, El Haj Assad M, Said Z, Elsaid K. Comparative analysis of liquid versus vapor-feed passive direct methanol fuel cells. Renewable Energy. 2019;131:563-84. 
[30] Xin S, Shen J, Liu G, Chen Q, Xiao Z, Zhang G, et al. High electricity generation and COD removal from cattle wastewater in microbial fuel cells with 3D air cathode employed non-precious Cu2O/reduced graphene oxide as cathode catalyst. Energy. 2020;196:117123.

[31] Sangeetha T, Li IT, Lan T-H, Wang C-T, Yan W-M. A fluid dynamics perspective on the flow dependent performance of honey comb microbial fuel cells. Energy. 2021;214:118928.

[32] Sayed ET, Tsujiguchi T, Nakagawa N. Catalytic activity of baker's yeast in a mediatorless microbial fuel cell. Bioelectrochemistry. 2012;86:97-101.

[33] Sayed ET, Shehata N, Abdelkareem MA, Atieh MA. Recent progress in environmentally friendly bioelectrochemical devices for simultaneous water desalination and wastewater treatment. Science of The Total Environment. 2020:141046.

[34] Tawalbeh M, Al-Othman A, Singh K, Douba I, Kabakebji D, Alkasrawi M. Microbial desalination cells for water purification and power generation: A critical review. Energy. 2020;209:118493.

[35] Olabi AG, Wilberforce T, Sayed ET, Elsaid K, Rezk H, Abdelkareem MA. Recent progress of graphene based nanomaterials in bioelectrochemical systems. Science of The Total Environment. 2020:141225.

[36] Zhou A, Liu Z, Wang S, Chen E, Wei Y, Liu W, et al. Bio-electrolysis contribute to simultaneous biohydrogen recovery and phosphorus release from waste activated sludge assisted with prefermentation. Energy. 2019;185:787-94.

[37] Sayed ET, Nakagawa N. Critical issues in the performance of yeast based microbial fuel cell. Journal of Chemical Technology \& Biotechnology. 2018;93(6):1588-94.

[38] Sayed ET, Barakat NAM, Abdelkareem MA, Fouad H, Nakagawa N. Yeast Extract as an Effective and Safe Mediator for the Baker's-Yeast-Based Microbial Fuel Cell. Industrial \& Engineering Chemistry Research. 2015;54(12):3116-22.

[39] Su L, Yin T, Du H, Zhang W, Fu D. Synergistic Improvement of Shewanella loihica PV-4 Extracellular Electron Transfer using a TiO2@ TiN Nanocomposite. Bioelectrochemistry. 2020:107519.

[40] Kondaveeti S, Lee S-H, Park H-D, Min B. Specific enrichment of different Geobacter sp. in anode biofilm by varying interspatial distance of electrodes in air-cathode microbial fuel cell (MFC).

Electrochimica Acta. 2020;331:135388.

[41] Ojima Y, Kawaguchi T, Fukui S, Kikuchi R, Terao K, Koma D, et al. Promoted performance of microbial fuel cells using Escherichia coli cells with multiple-knockout of central metabolism genes.

Bioprocess and Biosystems Engineering. 2020;43(2):323-32.

[42] Sayed ET, Abdelkareem MA. Yeast as a biocatalyst in microbial fuel cell. Old Yeasts-New Questions InTech. 2017:41-65.

[43] Stewart G. SACCHAROMYCES| Saccharomyces cerevisiae. 2014.

[44] Rossi R, Cavina M, Setti L. Characterization of electron transfer mechanism in mediated microbial fuel cell by entrapped electron mediator in saccharomyces cerevisiae. Chemical Engineering Transactions. 2016;49:559-64.

[45] Olotu T, Adegunloye D, Ekundayo F. Effect of Methylene Blue Addition as a Redox Mediator on Performance of Microbial Fuel Cell Using Mud Sediment of River Ala. Int J Cur Res Rev| Vol. 2019;11(17):18.

[46] Li Y, Liu L, Yang F, Ren N. Performance of carbon fiber cathode membrane with C-Mn-Fe-O catalyst in MBR-MFC for wastewater treatment. Journal of Membrane Science. 2015;484:27-34.

[47] Feng $Y$, Yang $Q$, Wang $X$, Logan BE. Treatment of carbon fiber brush anodes for improving power generation in air-cathode microbial fuel cells. Journal of Power Sources. 2010;195(7):1841-4.

[48] Choudhury P, Prasad Uday US, Bandyopadhyay TK, Ray RN, Bhunia B. Performance improvement of microbial fuel cell (MFC) using suitable electrode and Bioengineered organisms: A review.

Bioengineered. 2017;8(5):471-87. 
[49] Zhang X, Wang Q, Xia X, He W, Huang X, Logan BE. Addition of conductive particles to improve the performance of activated carbon air-cathodes in microbial fuel cells. Environmental Science: Water Research \& Technology. 2017;3(5):806-10.

[50] Kasem ET, Tsujiguchi T, Nakagawa N. Effect of Metal Modification to Carbon Paper Anodes on the Performance of Yeast-Based Microbial Fuel Cells Part I: In the Case without Exogenous Mediator. Conference Effect of Metal Modification to Carbon Paper Anodes on the Performance of Yeast-Based Microbial Fuel Cells Part I: In the Case without Exogenous Mediator, vol. 534. Trans Tech Publ, p. 76-81. [51] Barakat NAM, Moustafa HM, Nassar MM, Abdelkareem MA, Mahmoud MS, Almajid AA, et al. Distinct influence for carbon nano-morphology on the activity and optimum metal loading of $\mathrm{Ni} / \mathrm{C}$ composite used for ethanol oxidation. Electrochimica Acta. 2015;182:143-55.

[52] Farooqui U, Ahmad A, Hamid N. Graphene oxide: a promising membrane material for fuel cells. Renewable and Sustainable Energy Reviews. 2018;82:714-33.

[53] Olabi AG, Abdelkareem MA, Wilberforce T, Sayed ET. Application of graphene in energy storage device - A review. Renewable and Sustainable Energy Reviews. 2021;135:110026.

[54] Chee WK, Lim HN, Zainal Z, Huang NM, Harrison I, Andou Y. Flexible graphene-based supercapacitors: a review. The Journal of Physical Chemistry C. 2016;120(8):4153-72.

[55] ElMekawy A, Hegab HM, Losic D, Saint CP, Pant D. Applications of graphene in microbial fuel cells: The gap between promise and reality. Renewable and Sustainable Energy Reviews. 2017;72:1389-403. [56] Ji H, Sun H, Qu X. Antibacterial applications of graphene-based nanomaterials: recent achievements and challenges. Advanced drug delivery reviews. 2016;105:176-89.

[57] Christwardana M, Frattini D, Accardo G, Yoon SP, Kwon Y. Effects of methylene blue and methyl red mediators on performance of yeast based microbial fuel cells adopting polyethylenimine coated carbon felt as anode. Journal of Power Sources. 2018;396:1-11.

[58] Christwardana M, Frattini D, Accardo G, Yoon SP, Kwon Y. Early-stage performance evaluation of flowing microbial fuel cells using chemically treated carbon felt and yeast biocatalyst. Applied Energy. 2018;222:369-82.

[59] Christwardana M, Kwon Y. Yeast and carbon nanotube based biocatalyst developed by synergetic effects of covalent bonding and hydrophobic interaction for performance enhancement of membraneless microbial fuel cell. Bioresource Technology. 2017;225:175-82.

[60] Mishra A, Mehta A, Basu S, Shetti NP, Reddy KR, Aminabhavi TM. Graphitic carbon nitride (gC3N4)-based metal-free photocatalysts for water splitting: a review. Carbon. 2019.

[61] Zhu J, Nie W, Wang Q, Li J, Li H, Wen W, et al. In situ growth of copper oxide-graphite carbon nitride nanocomposites with peroxidase-mimicking activity for electrocatalytic and colorimetric detection of hydrogen peroxide. Carbon. 2018;129:29-37.

[62] Shah A, Zahid A, Subhan H, Munir A, Iftikhar FJ, Akbar M. Heteroatom-doped carbonaceous electrode materials for high performance energy storage devices. Sustainable Energy \& Fuels. 2018;2(7):1398-429.

[63] Jiang $T$, Jiang $G$, Huang $Q$, Zhou $H$. High-sensitive detection of dopamine using graphitic carbon nitride by electrochemical method. Materials Research Bulletin. 2016;74:271-7.

[64] Cai Z, Rong M, Zhao T, Zhao L, Wang Y, Chen X. Solar-induced photoelectrochemical sensing for dopamine based on TiO2 nanoparticles on g-C3N4 decorated graphene nanosheets. Journal of Electroanalytical Chemistry. 2015;759:32-7.

[65] Lu Q, Deng J, Hou Y, Wang H, Li H, Zhang Y. One-step electrochemical synthesis of ultrathin graphitic carbon nitride nanosheets and their application to the detection of uric acid. Chemical Communications. 2015;51(61):12251-3.

[66] Zou J, Wu S, Liu Y, Sun Y, Cao Y, Hsu J-P, et al. An ultra-sensitive electrochemical sensor based on 2D g-C3N4/CuO nanocomposites for dopamine detection. Carbon. 2018;130:652-63. 
[67] Zhang Y, Liu L, Van der Bruggen B, Yang F. Nanocarbon based composite electrodes and their application in microbial fuel cells. Journal of Materials Chemistry A. 2017;5(25):12673-98.

[68] Wang Y, Bai X, Qin H, Wang F, Li Y, Li X, et al. Facile one-step synthesis of hybrid graphitic carbon nitride and carbon composites as high-performance catalysts for $\mathrm{CO} 2$ photocatalytic conversion. ACS applied materials \& interfaces. 2016;8(27):17212-9.

[69] Fina F, Callear SK, Carins GM, Irvine JT. Structural investigation of graphitic carbon nitride via XRD and neutron diffraction. Chemistry of Materials. 2015;27(7):2612-8.

[70] Xu J, Zhang L, Shi R, Zhu Y. Chemical exfoliation of graphitic carbon nitride for efficient heterogeneous photocatalysis. Journal of Materials Chemistry A. 2013;1(46):14766-72.

[71] Xia P, Zhu B, Yu J, Cao S, Jaroniec M. Ultra-thin nanosheet assemblies of graphitic carbon nitride for enhanced photocatalytic CO2 reduction. Journal of Materials Chemistry A. 2017;5(7):3230-8.

[72] Abdelkareem MA, Al Haj Y, Alajami M, Alawadhi H, Barakat NAM. Ni-Cd carbon nanofibers as an effective catalyst for urea fuel cell. Journal of Environmental Chemical Engineering. 2018;6(1):332-7.

[73] Christwardana M, Frattini D, Duarte KD, Accardo G, Kwon Y. Carbon felt molecular modification and biofilm augmentation via quorum sensing approach in yeast-based microbial fuel cells. Applied energy. 2019;238:239-48.

[74] Duarte KD, Frattini D, Kwon Y. High performance yeast-based microbial fuel cells by surfactantmediated gold nanoparticles grown atop a carbon felt anode. Applied Energy. 2019;256:113912.

[75] Hidalgo D, Tommasi T, Bocchini S, Chiolerio A, Chiodoni A, Mazzarino I, et al. Surface modification of commercial carbon felt used as anode for microbial fuel cells. Energy. 2016;99:193-201.

[76] Hubenova Y, Rashkov R, Buchvarov V, Babanova S, Mitov M. Nanomodified NiFe-and NiFeP-carbon felt as anode electrocatalysts in yeast-biofuel cell. Journal of materials science. 2011;46(22):7074-81.

[77] Hubenova YV, Rashkov RS, Buchvarov VD, Arnaudova MH, Babanova SM, Mitov MY. Improvement of yeast- biofuel cell output by electrode modifications. Industrial \& engineering chemistry research.

2011;50(2):557-64. 